\title{
Advertising vs. R\&D: Relative effectiveness on brand equity
}

\author{
J. Jeong* \\ Graduate School of Pan-Pacific International Studies, Kyung Hee University, \\ Yongin-si, Gyeonggi-do, 440-701, Korea \\ *To whom all correspondence should be addressed \\ profjeong@khu.ac.kr
}

\begin{abstract}
This study examines whether advertising can contribute directly to brand equity and, if it can, determines how much value advertising can deliver to brands and firms using the secondary data from various sources. The findings show that advertising can not only work to improve market performance measures but also to develop and maintain brand equity. $R \& D$ is also found to positively affect brand equity. With regard to the relative effectiveness of advertising and $R \& D, R \& D$ is more effective than advertising in contributing to brand equity when measuring absolute effects of expenditures. When measuring simple changes in brand equity, however, changes in advertising are more effective than changes in $R \& D$.
\end{abstract}

This work was supported by a research grant from Kyung Hee University in 2011 (KHU-20110465).

\section{Introduction}

Since the first formal advertising model, AIDA (AttentionInterest-Desire-Action) was introduced by E. St. Elmo Lewis in 1898 (Strong 1925), the effectiveness of advertising has been an issue in marketing (Borden 1952). Marketing managers have shown tremendous interest in forecasting sales, and in response, academic researchers mainly of economics and statistics backgrounds endeavoured to examine the role of advertising in forecasting sales using econometric methods, such as single equation models with cross-sectional data or simultaneous equation models with time-series data (Telser, 1962; Palda, 1964; Quandt, 1964; Bass 1969). For example, Telser (1964) used simultaneous equation models with time-series data from three different cigarette brands marketed in the United States to explore the relationship between advertising and sales.

Because this research primarily focuses on market or sales response to advertising, it has been referred to as market or sales response analysis (Vakratsas \& Ambler, 1999). During the 1960 s, researchers tried various statistical models to find the one that could best explain advertising-sales relationships, but no general consensus was made. Rather, these studies generated more questions than answers and showed that advertising-sales relationships could be influenced by other marketing activities of the firm and/or competitors, as well as by exogenous variables such as population and income (Telser, 1962; Palda, 1964; Quandt, 1964). In Telser's (1962) study, he found that the brand of cigarettes and time of data collection affected the level of return on advertising (Telser, 1962). Thus, Telser suggested that managers should consider variables like economic condition and level of competition in the market when estimating the effect of advertising on sales (Telser, 1962, 1964). Quandt (1964) also argued in his study employing both cross-sectional and time-series models that economic variables such as disposable income and geographic-demographic variables like education should be considered as exogenous variables, which can affect the relationship between advertising and sales.

Despite the lack of agreement on statistical methods and the prevalence of unreliable data in the econometric analyses of the 1960s (Quandt, 1964), marketing efforts of business organizations were intuitively believed to influence market performance measures. Consequently, many academic researchers continued to use the market response analysis approach. Since the 1970s, with increased reliability of data and improved statistical programs, the research stream has diversified with expanded focus towards other marketing mix variables including sales promotion measures, and other market performance variables, such as market share (Bass and Clarke 1972). Compared with studies completed prior to 1970s when marketing managers in business organizations faced more specific issues like the ROI (return on investment) on marketing variables, thus needed to manage them strategically, more marketing researchers were involved in doing research using the market response analysis approach (Assmus, et al., 1984; Sethuraman \& Tellis, 1991; Parker \& Gatignon, 1996).

The market response analysis approach generally relates advertising as well as price and promotional measures directly to market performance measures such as sales, market share, and brand choice (Vakratsas \& Ambler, 1999). Some studies adopting market response models, in the quest to understand advertising effectiveness, concerned with market-level data, including brand advertising expenditures and brand sales or market share (Bass \& Clarke, 1972; Blattberg \& Jeuland, 1981; Bruce, et al., 2012; Hanssens, et al., 1990; Kim, 2007; Rao \& Miller, 1975; Zhou, et al., 2003; Joshi \& Hanssens, 2009). While such studies have focused on the traditional advertising medium, more recent studies focused on the new media advertisings with the introduction 
of the Internet and the smart devices (Breuer, Brettel \& Engelen, 2011; Park, Shenoy \& Salvendy, 2008). Others examined individual-level data such as the number of exposures for an individual and individual brand choice (Tellis, 1988; Pedrick \& Zufryden, 1991; Deighton, et al., 1994; Terui, et al., 2011).

Like the earlier studies, these studies resulted in questionable and conflicting findings regardless of the contribution in revealing more advanced and in-depth knowledge about the role of marketing efforts. For example, Leone (1995) suggested that advertising's effects on sales would disperse after six to nine months instead of earlier estimates (Assmus, et al., 1984) of three to fifteen months. In contrast, Winer (1979) suggested that even though carryover effects would decline over time, current advertising effects would increase during the same period. However, it has been found that the absence of advertising leads consumers to forget, thus it is important to carry out advertising efforts with various themes for revitalization of messages (Bass, et al., 2007). Dekimpe and Hanssens (1995) argued that the effects of advertising did not dissipate within a year. One study employing a metaanalysis of 389 real world split cable TV advertising experiments by Lodish and colleagues (Lodish, et al., 1995) revealed that in only 33 percent of the cases investigated showed increased sales of established brands with greater weight on advertising (55 percent for new brands). According to Vakratsas and Amber (1999), it is generally believed that the effects of advertising on sales are low, with elasticities typically in the range of 0 to .2 , and the effects of short-term promotions are larger than those of advertising (Deighton, et al., 1994; Tellis, 1988). The results of these studies appear to be largely dependent on the product or product category investigated or the data used in the research (Vakratsas \& Amber, 1999).

To some extent, the traditional view for the role of advertising in market (sales) response analysis has contributed in explaining the relationship between advertising and sales within business organizations. However, there still is no consensus regarding the relationship between advertising and sales. While other marketing variables such as sales promotion can affect the advertising-sales relationship (Neslin, 2002), the results of studies done by marketing researchers are not consistent enough to draw a clear conclusion about this relationship (Vakratsas \& Amber, 1999).

\section{New approach: Market-based assets}

Since academic researchers have not been able to provide a comprehensive explanation of the advertising-sales relationship with market response analysis, the role of advertising and it re-examination should be warranted at this time. Should advertising always be related to market performance measures? If it should, how can we explain that advertising supposedly builds brand image instead of selling products? Is there any different ways to analyse the value of advertising inside and/or outside the marketing context? Can advertising function as a value-generator rather than a resource-sink for firms and their brands? Can we empirically show marketing managers that advertising is an investment?

The alternative framework this study uses to explore these questions is based on a theoretical contribution by Srivastava, Shervani and Fahey (1998) emphasizing the marketingfinance interface. Given the approach of adopting the interface of marketing and finance in measuring the effect of marketing activities, according to Srivastava and his colleagues (1998), the ultimate purpose of marketing activities should be to enhance shareholder value by "cultivating and leveraging market-based assets" (p. 2) (Ramaswami, et al., 2009). Market-based assets consist of two related types: relational and intellectual (Srivastava, et al., 1999). Such assets are mainly external to the firm, generally do not appear on the balance sheet, and are largely intangible (Hall, 1993). Even so, these assets can be "developed, augmented, leveraged, and valued" (Srivastava et al., 1998, p.4) in order to contribute towards values for consumers and firms (Hunt \& Morgan, 1995).

Relational market-based assets are usually the outcomes of relationships between a firm and key outside stakeholders, such as distributors, retailers, end customers, and other strategic partners (Sheth \& Parvatiyar, 1995). Two examples suggested by Srivastava and colleagues (1998) that can play a key role in enhancing relational market-based assets are brand equity and channel equity. Brand equity is defined as the marketing effects or outcomes that accrue to a product with its brand name, compared to that of the same product only without the brand name (Aaker, 1991; Ailawadi, et al., 2003; Burmann, et al., 2009; Keller, 1993; Rust, et al., 2004b; Vargo \& Lusch, 2004). Extensive advertising and superior product quality can result in brand equity. Channel equity, also known as relationship equity, can be defined as the outcomes or effects of unique, long-standing, and successful business relationships between a firm and key channel members (Srivastava et al., 1998).

Intellectual market-based assets consist various types of knowledge or information a firm possesses about the market environment including information about competitors, customers, and channels (Clulow, et al., 2007; Glazer, 1991; Srivastava et al., 1998). Based on this knowledge or information, a firm can develop its own strategy to deal with the strengths and weaknesses of its products or services, and with opportunities and threats within the environment. Research and development (R\&D) can help a firm acquire information or knowledge to develop a new product or service. Research and development can enhance intellectual market-based assets and, in turn, develop marketing strategies to compete with other competitors in the market (Frels, et al., 2003; O’Brien, 2003). These marketing strategies can result in value for the brand and the firm (Lin, et al., 2006).

These relational and intellectual market-based assets can intertwine to create a unique competitive edge for a firm in a marketplace (Srivastava, et al., 1998). For example, stronger customer relationships could be created when a firm uses knowledge about buyer needs and preferences to build longterm relationship bonds with external entities such as 
customers and distributors (Srivastava, et al., 1998). The importance of these market-based assets has also been emphasized by other marketing researchers (Daidj, et al., 2004; Dahlhoff, 2002; Rust, et al., 2004a). Brand equity (Shocker, Srivastava \& Ruekert, 1994; Pahud de Mortanges \& Van Riel, 2003), customer satisfaction (Anderson, et al., 2004), and the management of strategic relationships (Morgan \& Hunt, 1994) are the underlying concepts of market-based assets, whether it is relational market-based assets, intellectual market-based assets, or both. Other assets that have been subjected for observation included customer equity, perceived product quality, and channel structure (Aaker \& Jacobson, 1994; Anderson, et al., 2004; Ramaswami, et al., 2009; Srinivasan \& Hanssens, 2009).

Unlike other tangible assets in business organizations, such as plant and equipment, raw materials, and finished products, the value of market-based assets is hard to measure and does not appear on the balance sheet. For these reasons, many firms still consider expenditures for marketing activities as an expense rather than an investment. However, market-based assets can also function in the exact same way as any other tangible assets that are believed to be an investment, doing so by way of "lowering costs, attaining price premiums, generating competitive barriers, providing a competitive edge by making other resources more productive, and providing managers with options" (Srivastava, et al., 1998, p. 6).

\section{The impact of advertising and R\&D on market- based assets}

Advertising can enhance competitive customer relationships and partner relationships through unique values delivered to firm stakeholders like buyers and channel members (Srivastava, et al., 1998, 1999). The relationships with customers and partners are essential characteristics of relational market-based assets. Therefore, a firm's advertising can improve relational market-based assets by communicating its efforts with a firm's stakeholders. One of the key roles advertising plays in the market is to increase brand awareness and promote favourable brand attitudes. Thus, advertising can contribute to development and maintaining of relational market-based assets through communication with customers and partners (Srivastava, et al., 1998; Chu \& Keh, 2006; Rust, et al., 2004a; Srinivasan, 2006).

R\&D can influence and accelerate the development of new products and services by utilizing information and knowledge about the market environment, which are the typical examples of intellectual market-based assets. Hence, the new products and services are the outcomes of a firm's intellectual market-based assets that are influenced by a firm's R\&D efforts.

Brand equity comes from customer brand name awareness, brand loyalty, perceived brand quality, and favourable brand symbolism and associations that provide a platform for a competitive advantage and future earning streams (Aaker, 1991; Kerin \& Sethuraman, 1998). It is believed that brand equity can be a surrogate measure of market-based assets in the present research. This is because a firm with superior market-based assets is more likely to have high brand equity, which in turn works as an intangible asset for the firm in improving market performance the way market-based assets do.

Brand equity is generally believed to be the outcome of marketing and R\&D efforts for a product (Keller, 1998; Srivastava, et al., 1998; Wang, 2010). According to Leuthesser (1988), from the firm's perspective, brand equity can be the incremental cash flow resulting from a product with a brand name compared with a product without one (Kim, et al., 2003; Seggie, et al., 2006). From the consumer's perspective, brand equity can be a utility, loyalty, or clear differentiated image not explained by product attributes.

Advertising can play a key role in achieving superior brand equity by communicating with potential customers (Ailawadi, et al., 2003; Srivastava, 1998; Buil, de Chernatony \& Martínez, 2013; Eng \& Keh 2007; Sriram, et al., 2007; Wang, et al., 2009). R\&D can also contribute to brand equity by helping a firm to be equipped with knowledge and information about customers and competitors to survive in the market. Knowledge and information are essential in developing new products and services, which can generate superior brand equity. This knowledge and information sometimes can be acquired through the relationships built around a firm's customers and channel members (Srivastava, et al., 1998). The relationship of three important components - advertising, market-based assets, and shareholder value - is portrayed in Figure 1.

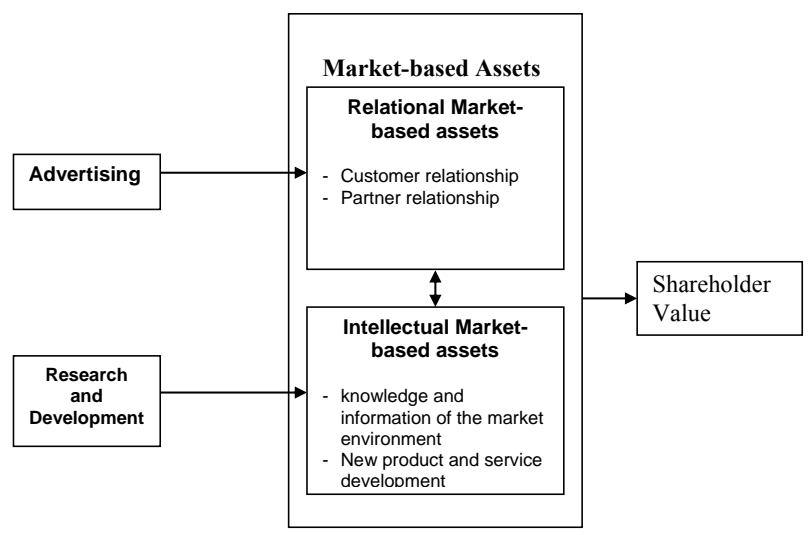

Figure 1: Conceptual framework

\section{Hypotheses}

\section{Advertising}

Advertising plays a key role in communicating product availability, features, and benefits, and building a firm's image. Brand image generated by advertising in turn contributes to brand equity (Keller 1998; Bowman and Gatignon 2010) by improving brand awareness and cultivating favourable brand attitudes (Aaker, 1991; Buil, et al., 2013; Chu \& Keh, 2006; Keller, 1993). Advertising, as a 
variable that can play a vital role in the process of creating brand value, can be analysed in two ways: absolute expenditures and changes in expenditures. The present research is not only interested in the absolute advertising expenditures but also in changes in advertising expenditures that can be used to explain the marginal effect of advertising on brand equity. It is possible that there might be differences between these two ways of measuring the effects of advertising. Therefore, hypotheses regarding the advertising in the process of creating brand value can be stated as follows.

Hla: There is a positive relationship between gross advertising expenditures and brand equity.

H1b: There is a positive relationship between changes in advertising expenditures and changes in brand equity.

\section{Research and development}

Research and development (R\&D) also can have a positive effect on brand equity and shareholder value by improving intellectual market-based assets (Keller, 1998; Kim, et al., 2003; Seggie, et al., 2006; Srivastava, et al., 1998; Wang, 2010). Well-managed intellectual market-based assets can generate higher shareholder value by providing information necessary for developing new technology and stimulating new product and service development (Clulow, et al., 2007). This R\&D can also be examined in two ways: gross R\&D expenditures and changes in R\&D expenditures. Like advertising, hypotheses on $\mathrm{R} \& \mathrm{D}$ as an element in creating brand equity can be summarized as follows.

H2a: There is a positive relationship between gross $R \& D$ expenditures and brand equity.

$H 2 b$ : There is a positive relationship between changes in $R \& D$ expenditures and changes in brand equity

\section{Advertising vs. R\&D}

Advertising and R\&D are interdependent. In general, advertising and $R \& D$ are believed to compete for available funds in business organizations (Sridhar, et al., 2014; Vinod $\&$ Rao, 2000). Firms allocate their limited resources to the fundamental processes of generating value, mainly between creating value (innovating, producing and delivering new products to the market) and appropriating value (making profits in the marketplace), thus leading to trade-offs between advertising and R\&D (Chu \& Keh, 2006; Mizik \& Jacobson, 2003).

According to Mizik and Jacobson (2003), the superior market performance resulting from a sustainable competitive advantage is the outcome of the firm's two main types of capabilities: superior customer-value creation capabilities and value appropriation capabilities. The value creation process is closely linked to a firm's R\&D activities, whereas the value appropriation process is basically related to a firm's advertising activities. Mizik and Jacobson (2003) found that the stock market reacts favourably when a firm increases its emphasis on value appropriation relative to value creation (Eng \& Keh, 2007). This suggests that advertising has more capabilities than R\&D to enhance brand equity and, in turn, shareholder value. Therefore, in terms of the relative effectiveness of advertising and $\mathrm{R} \& \mathrm{D}$, hypothesis 3 can be stated as follows.

H3: Advertising is more effective than $R \& D$ in contributing to brand equity.

\section{Methodology}

The proposed research hypotheses were evaluated by the means of a series of regression analyses with secondary data in order to examine the relationships between advertising, $\mathrm{R} \& \mathrm{D}$, and brand equity. This section has been divided into two: operationalisations of variables and data collection. First, the variables used in the present research are discussed in detail and description of their respective operationalisations. Next, the data sources and method of collecting data are presented, followed by a discussion regarding the criteria used when selecting firms to investigate.

\section{Operationalisations of variables}

\section{Advertising}

As discussed before, many market response models probing into the relationship between advertising and market performance measures can be classified either into aggregatelevel or individual-level models based on the data used. Aggregate-level data include sales or market share; individual-level data are measures like brand choice (Vakratsas \& Ambler, 1999). Most aggregate-level studies incorporating a quantitative methodology have traditionally utilized advertising expenditures in their analyses (Erickson \& Jacobson, 1992; Joshi \& Hanssens, 2010). Even though the present research develops a non-traditional approach to shed light on the effects of advertising in business organizations, it is believed that the best method of quantifying "advertising" is to use the actual expenditures on advertising by firms. Therefore, advertising is operationalized and measured as firms' actual annual expenditures on advertising.

\section{Research and development}

An extensive literature in economics has documented a positive effect of Research and Development (R\&D) significant on economic growth and productivity (Solow, 1957; Guellec \& Van Pottelsberghe de la Potterie, 2004). Denison (1962) reported that approximately 40 percent of the total increase in per capita national income was attributable to technological change. In spite of a slight difference in estimates of R\&D effects, Griliches (1995) showed that all recent studies of $R \& D$ continuously report significant returns from it. It is believed that firm value can be created both through product innovations and process innovations by a firm, which are outcomes of a firm's R\&D efforts (Ho, et al., 2005; Mansfield, et al., 1977). Therefore, like most studies of 
R\&D (Mizik \& Jacobson, 2003; Joshi \& Hanssens, 2010), $\mathrm{R} \& \mathrm{D}$ is measured as the actual annual expenditures on research and development.

\section{Brand equity}

As discussed above, brand equity is an intangible firm asset with an economic value, in the sense that a firm with high brand value products worth more than a firm without them (Aaker, 1991, 1996; Keller, 1993). Brand equity comes from customer brand name awareness, brand loyalty, perceived brand quality, and favourable brand symbolism and associations that provide a platform for a competitive advantage and future earning streams (Aaker \& Jacobson, 2001; Kim, et al., 2003; Seggie, et al., 2006). Brand value, as mentioned, is the most commonly used operationalization of brand equity in the area of branding (Keller, 1998) and brand value estimates by Financial World and Interbrand Group have been used in other studies, such as that of Kerin and Sethuraman (1998). Therefore, it is believed that brand equity can be operationalized and measured as brand value estimates for the present research.

\section{Data}

Advertising expenditures data from 1991 to 1996 and from 1999 to 2012 were obtained from Standard \& Poor's Compustat PC-Plus database. This database provides annual accounting and stock market information for publicly traded firms on the New York, American, and NASDAQ stock exchanges. The database is one of the most widely used secondary data sources by academic researchers and is believed to be reliable for this type of research (Srinivasan, et al., 2009; Wang, et al., 2009). Data for R\&D expenditures also were obtained from Standard \& Poor's Compustat PCPlus database.

Brand value estimates data were collected for two different time periods from two different data sources. The first data set, for 1991-1996, comes from "Measuring the Impact of Brand Management," which were published every August in Financial World $(F W)$ during the period of 1991-1996. The second data set, for 1999-2012, comes from Interbrand Group's website, "The 100 Best Global Brands by Value." Brand value estimates data were first introduced by $F W$ and made available to the public in 1991 and since the data was announced annually until it went out of business in 1997. In $1995, F W$ slightly changed its brand valuation method based on the Interbrand valuation model approach for a more accurate and credible estimation of the value of brands (Meschi, 1995).

Interbrand Group has reported the annual brand value estimates for "The 100 Best Global Brands by Value" since 1999. The estimates by Interbrand Group, a brand consulting company headquartered in London, England, were published again in Business Week in 1999 for the first time since 1997. Since then, Interbrand Group has reported brand value estimate for the 100 best global brands every August. These two data sets together make a total span of 20 years of brand value estimates (1991 - 2012 except 1997 and 1998). Data sets are not only unique but also reliable and publicly available in a form amenable to a statistical analysis.

The fact that the focal brand for brand value estimates should be a corporate brand rather than a product or service brand was the criterion that determined which brands should be included in the analysis sample. This criterion was used to avoid any potential problems due to the different units of analysis. Since the advertising expenditures available from the Compustat PC-Plus database were reported only as an aggregate number for all of a firm's brands, it was necessary to employ only corporate brand values (Herremans, et al., 2000). Lists of brand value estimates by Financial World and Interbrand generally included 100 brands, but a brand listed last year might have not been listed this year. Therefore, the total number of corporate brands available for the present research, during the period 1991-1996 and 1999-2012, was larger than the number of corporates listed available in any one year for brand value estimates. Any variables with missing data were treated as variables without value and thus excluded from any statistical analyses involving them.

In addition to the data obtained from various sources such as the Compustat PC-Plus database and Financial World, two additional forms of data were also developed for further statistical analyses: change data and weighted data. Change data were obtained from the original data by subtracting gross measures in year $t$ from gross measures in year $t+1$. For example, changes in advertising expenditures in 1994 were calculated by subtracting gross measures of advertising expenditures in 1993 from gross measures of advertising expenditures in 1994. In addition to the change data in advertising expenditures, other primary variables like changes in $R \& D$ expenditures and changes in brand value estimates were also obtained in the same way that changes in advertising expenditures were obtained. Change data were of interest in the present research because they could provide a perspective on the marginal effects of variables. These marginal effects may tell a different story to that of the gross effects of variables.

With regards to the weighted data, during the twenty years of time period starting from 1991 to 1996 and 1999 to 2012, there were more data available for some corporate brands than for the others. For example, Accenture, Inc. and Maytag, Inc. were listed only once in the whole of twenty-year span, whereas Coca-Cola and Kodak have been included almost annually. For these differences related to the number of representations in the data could cause unbalanced effects on the analyses, thus, the original data were weighted to reduce the possible unbalanced effects and each observation was represented equally in the analyses. In addition to the original data, the change data, obtained by subtracting gross measures of variables in year $t$ by gross measures of variables in year $t+1$, were also weighted. 


\section{Results}

\section{Test of brand value estimates}

In order to test the effects of having pre-1995 data sets in the regression analyses, a dummy variable with values " 0 " and " 1 " was created and put into a regression model. The dummy variable " 0 " represented data sets before 1995 and the dummy variable " 1 " represented data sets after 1995. The regression model can be described as follows

Brand Equity $=a+b_{1}$ (advertising $)+b_{2}(R \& D)+b_{3}$ (dummy) + error

where a is a regression intercept and

$b_{1}, b_{2}$, and $b_{3}$ are regression slopes for the independent variables.

Beta coefficients for the dummy variable with the original data and the weighted data were .095 and .049 respectively. Beta coefficients for the dummy variable with the original change data and the weighted change data were -.008 and .006 respectively. None of those beta coefficients were statistically significant. Therefore, it was concluded that the data source and time period (before and after 1995) did not affect the regression analyses.

\section{Advertising and brand equity}

In order to test H1a ("There is a positive relationship between gross advertising expenditures and brand equity"), a simple regression model was used. The values of beta standardized coefficients were .476 and .501 respectively and both were statistically significant at $\mathrm{p}<.01$ and the values of $\mathrm{R}^{2}$ were .226 and .251 for the analysis with the original data and the analysis with the weighted data respectively.

In addition, the values of overall model fit F-statistic, which was $86.2(p<.01)$ for the original data and $218.47(p<.01)$ for the weighted data, indicate that the regression model used to explain the relationship between advertising and brand value in the analysis performed well in predicting brand value. Comparing the two regression models, one with the original data and the other with the weighted data, the latter, the weighted data, showed a little better result than the former, with the original data, with regard to $\mathrm{R}^{2}$ and F-value. Based on the statistical significance of the beta coefficients, $\mathrm{R}^{2}$ values, and overall model fit $F$-statistics, H1a was accepted.

A simple regression analysis was also performed to test $\mathrm{H} 1 \mathrm{~b}$, "There is positive relationship between changes in advertising expenditures and changes in brand equity." As discussed, changes in brand equity were operationalized as changes in brand value estimates and measured by subtracting brand value estimates in year t from brand value estimates in year $t+1$ for all observations in the original data. Changes in advertising expenditures were measured in the same way that changes in brand value estimates were, which included subtracting advertising expenditures in year $\mathrm{t}$ from advertising expenditures in year $\mathrm{t}+1$.

In addition to the original change data, the weighted change data were calculated and used to determine if there were any discrepancies between these two data sets. The beta coefficients for these two regression models, one with the original change data and the other with the weighted change data, were .167 and .212 respectively. The beta coefficient for the original change data was statistically significant at $p<.05$, whereas the beta coefficient for the weighted change data was statistically significant at $p<.01$. The values of $\mathrm{R}^{2}$ were .028 and .045 for the analysis with the original change data and the analysis with the weighted change data respectively. In addition, the values of the overall model fit F-statistic, which were $5.25(p<.05)$ for the original change data and 16.48 $(p<.01)$ for the weighted change data, reveal that the regression model with the weighted changes data produced slightly better results than the regression model with the original change data. Considering the statistical significance of measures in the two regression models, one with the original change data and the other with the weighted change data, H1b, "There is a positive relationship between changes in advertising expenditures changes in brand equity," is accepted.

\section{$R \& D$ and brand equity}

In order to test $\mathrm{H} 2 \mathrm{a}$, "There is a positive relationship between R\&D expenditures and brand equity," a simple regression analysis was performed. As mentioned above, in addition to the original data, the weighted data were used to reduce the potential bias by over-representations of certain corporate brands in the regression model and ascertain the accuracy of the analyses.

The beta standardized coefficients were .544 and .546 respectively and both were statistically significant at $\mathrm{p}<.01$. The values of $\mathrm{R}^{2}$ were .296 and .298 for the regression analyses with the original data and the weighted data respectively. The values of the overall model fit F-statistic, which were $139.62(p<.01)$ for the original data and 338.48 $(p<.01)$ for the weighted data, indicated that the regression model employed performed well in predicting brand equity. Therefore, H2a was accepted.

A simple regression analysis was done to test $\mathrm{H} 2 \mathrm{~b}$, "There is a positive relationship between changes in $R \& D$ expenditures and changes in brand equity." As before, the beta coefficients in the two regression models, one for the original change data and the other for the weighted change data, were the same, .103. However, unlike the previous regression models, the beta coefficient for the original change data was not statistically significant, whereas the beta coefficient for the weighted change data was marginally significant at $\mathrm{p}<.05$. Furthermore, the values of $\mathrm{R}^{2}$ were .011 for both the original change data and the weighted change data. 
In addition, the values of the overall model fit F-statistic were 2.22 and 4.86. The F-value of 2.22 for the original change data was not statistically significant. The F-value of 4.86 for the weighted change data was marginally significant. However, the difference in statistical significance between these two F-values probably resulted from the difference in the sample sizes between the two data sets. Therefore, considering the beta coefficients, the values of $\mathrm{R}^{2}$, and $\mathrm{F}$ values with these two regression models, it was determined that $\mathrm{H} 2 \mathrm{~b}$, "There is a positive relationship between changes in R\&D expenditures and changes in brand equity," could not be accepted.

\section{Advertising vs. R\&D}

The third hypothesis (H3), "Advertising is more effective than R\&D in contributing to brand equity," was empirically tested with all four types of data: the original data, the weighted data, the original change data, and the weighted change data. In order to test $\mathrm{H} 3$, the multiple regression model was developed as follows.

Brand Equity $=a+b_{1}($ advertising $)+b_{2}(R \& D)+$ error

where a is a regression intercept and

$b_{1}$ and $b_{2}$ are regression slopes for independent variables.

Regarding H3, "Advertising is more effective than R\&D in contributing to brand equity," the magnitude of the beta coefficients for advertising expenditures and R\&D expenditures can be compared to assess the relative effectiveness of advertising and R\&D. The beta coefficients for advertising and R\&D for all observations were .130 $(p<.05)$ and $.574(p<.01)$ respectively for the original data and the weighted data. Since the beta coefficient of R\&D was greater than that of advertising, $R \& D$ was believed to contribute more to brand equity than advertising for the total observations in terms of dollar expenditures.

The beta coefficients for advertising and R\&D for all observations with the weighted data were $.198(\mathrm{p}<.01)$ and $.501(\mathrm{p}<.01)$ respectively. The beta coefficient for $R \& D$ was greater than that for advertising, although both were statistically significant at $p<.01$. These coefficients confirmed the findings from the regression analyses using the original data, which indicated that $R \& D$ was more effective than advertising in increasing brand equity. Therefore, contrary to H3, R\&D was more effective than advertising in contributing to brand equity in terms of absolute dollars.

The beta coefficients for advertising and $R \& D$ for all observations with the original change data were .200 and .020 respectively. The beta coefficient for advertising was greater than that of $R \& D$ and statistically significant at $\mathrm{p}<.05$; the beta coefficient for R\&D was not statistically significant. Unlike the previous findings from the regression analyses using the original data and the weighted data, these beta coefficients showed that advertising was more effective than $R \& D$ in contributing to changes in brand equity in terms of expenditure changes. In other words, changes in advertising expenditures were more effective in contributing to changes in brand equity than were changes in $\mathrm{R} \& \mathrm{D}$ expenditures.

The beta coefficients for advertising and $R \& D$ for all observations with the weighted change data were .237 and .035 respectively. The beta coefficient for advertising was greater than that for $\mathrm{R} \& \mathrm{D}$, and the beta coefficient for advertising was statistically significant at $\mathrm{p}<.01$; the beta coefficient for $R \& D$ was not statistically significant. Analogous to the previous findings from the regression analyses using the original change data, these beta coefficients showed that advertising was more effective than $\mathrm{R} \& \mathrm{D}$ in contributing to changes in brand equity. This means that changes in advertising were more effective in contributing to changes in brand equity than changes in $R \& D$ expenditures.

To summarize, based on the regression analyses with all four types of data, the original data, the weighted data, the original change data, and the weighted change data, it appeared that absolute $R \& D$ expenditures were more closely related than absolute advertising expenditures to brand equity, but changes in advertising expenditures were more effective than changes in $R \& D$ expenditures in increasing brand equity. Therefore, H3, "Advertising is more effective than R\&D in contributing to brand equity," was partially supported.

Table 1 and Table 2 summarize the results of hypothesis testing. Beta coefficients for each hypothesis reflecting the statistically significant relationships are shown in Table 1 and the hypotheses are presented in an abbreviated form representing the relationships between the variables tested in Table 2. 
Table 1: Beta coefficients for hypotheses

\begin{tabular}{|c|c|c|c|c|c|c|c|c|c|c|c|}
\hline \multirow[t]{2}{*}{ Hypothesis } & \multicolumn{3}{|c|}{ Variable } & \multirow{2}{*}{\multicolumn{2}{|c|}{ Original Data }} & \multirow{2}{*}{\multicolumn{2}{|c|}{ Weighted Data }} & \multirow{2}{*}{\multicolumn{2}{|c|}{$\begin{array}{c}\text { Original Change } \\
\text { Data }\end{array}$}} & \multirow{2}{*}{\multicolumn{2}{|c|}{$\begin{array}{c}\text { Weighted Change } \\
\text { Data }\end{array}$}} \\
\hline & DV & IV & $\begin{array}{c}\text { IV2 or } \\
\text { Covariate }\end{array}$ & & & & & & & & \\
\hline H1a & $\begin{array}{l}\text { Brand } \\
\text { Equity }\end{array}$ & Adv & & \multicolumn{2}{|c|}{$.476 * *$} & \multicolumn{2}{|c|}{$.501 * *$} & & & & \\
\hline H1b & $\begin{array}{l}\text { Change } \\
\text { in } \\
\text { Brand } \\
\text { Equity }\end{array}$ & $\begin{array}{l}\text { Change in } \\
\text { Adv }\end{array}$ & & & & & & \multicolumn{2}{|c|}{$.167 *$} & \multicolumn{2}{|c|}{$.212 * *$} \\
\hline $\mathrm{H} 2 \mathrm{a}$ & $\begin{array}{l}\text { Brand } \\
\text { Equity }\end{array}$ & R\&D & & \multicolumn{2}{|c|}{$.544 * *$} & \multicolumn{2}{|c|}{$.546 * *$} & & & & \\
\hline $\mathrm{H} 2 \mathrm{~b}$ & $\begin{array}{l}\text { Change } \\
\text { in } \\
\text { Brand } \\
\text { Equity }\end{array}$ & $\begin{array}{l}\text { Change in } \\
\text { R\&D }\end{array}$ & & & & & & \multicolumn{2}{|c|}{ ns } & \multicolumn{2}{|c|}{$.103 *$} \\
\hline $\mathrm{H} 3$ & $\begin{array}{l}\text { Brand } \\
\text { Equity }\end{array}$ & Advertising & R\&D & $.130 *$ & $.574 * *$ & $.198 * *$ & $.501 * *$ & $.200 *$ & $\mathrm{~ns}$ & $.237 * *$ & $\mathrm{~ns}$ \\
\hline
\end{tabular}

** Regression Coefficient is significant at the 0.01 level (2-tailed).

* Regression Coefficient is significant at the 0.05 level (2-tailed).

Note: DV and IV refer to dependent variable and independent variable respectively. Adv refers to advertising. NS refers to not supported and ns refers to not statistically significant.

Table 2: Summary of hypothesis tests

\begin{tabular}{l|l|c}
\hline \multicolumn{1}{|c|}{ Hypothesis } & Results \\
\hline H1a & $\begin{array}{l}\text { There is a positive relationship } \\
\text { between gross advertising } \\
\text { expenditures and brand equity. }\end{array}$ & supported \\
\hline H1b & $\begin{array}{l}\text { There is positive relationship } \\
\text { between changes in advertising } \\
\text { expenditures and changes in } \\
\text { brand equity. }\end{array}$ & supported \\
\hline H2a & $\begin{array}{l}\text { There is a positive relationship } \\
\text { between R\&D expenditures and } \\
\text { brand equity. }\end{array}$ & supported \\
\hline H2b & $\begin{array}{l}\text { There is a positive relationship } \\
\text { between changes in R\&D } \\
\text { expenditures and changes in } \\
\text { brand equity. }\end{array}$ & $\begin{array}{c}\text { partially } \\
\text { supported }\end{array}$ \\
\hline $\begin{array}{l}\text { Advertising is more effective } \\
\text { than R\&D in contributing to } \\
\text { brand equity. }\end{array}$ & not supported \\
\hline
\end{tabular}

\section{Discussion and implications}

The role of advertising in enhancing brand equity was confirmed when the relationship between advertising and brand equity was analysed using a simple regression model. As discussed, brand equity is the core concept of the present research. A firm's advertising and R\&D can develop and improve market-based assets (relational market-based assets and intellectual market-based assets), which in turn can be represented by brand equity (Keller, 1998; Kim et al., 2003; Seggie, et al., 2006; Srivastava, et al., 1998; Wang, 2010). Therefore, brand equity can be considered as a surrogate measure of market-based assets for a firm with superior market-based assets is more likely to have superior brand equity and, with brand equity, a firm can generate more values for the firms.

Advertising for corporate brands had relatively strong associations with brand equity. In addition, changes in advertising were positively related to changes in brand equity. This means that increases (decreases) in expenditures on advertising lead directly to increases (decreases) in brand value estimates. In other words, advertising can actually increase brand equity by developing relational market-based assets as proposed in the conceptual model.

Like advertising, the relationships between R\&D and brand equity was confirmed in the present research. R\&D for corporate brands showed a strong association with brand equity. Furthermore, changes in $\mathrm{R} \& \mathrm{D}$ had a positive effect on changes in brand equity, indicating that increases (decreases) in expenditures on $\mathrm{R} \& \mathrm{D}$ can contribute to increases (decreases) in brand value estimates. These findings show that the potential of $R \& D$ in enhancing brand equity can be realized by improving intellectual market-based assets. Since the present research shows that R\&D can contribute to brand equity, managers can take advantage of these findings and consider $\mathrm{R} \& \mathrm{D}$ as a legitimate option to generate value for brands and firms in the future.

With regard to the relative effectiveness of advertising and $\mathrm{R} \& \mathrm{D}$ in contributing to brand equity, the theoretical argument stating that advertising is more effective than $R \& D$ in contributing to brand equity was not statistically confirmed across the four types of data analysed: the original data, the weighted data, the original change data, and the weighted change data. The multiple regression analyses found inconsistent patterns of relationships. For example, beta coefficients for R\&D with the original data and the weighted data were greater than those for advertising, whereas the beta coefficients for advertising for the original change data and the weighted change data were greater than the beta coefficients for R\&D.

The findings of the multiple regression analyses actually provide intriguing perspectives on the relative effectiveness of advertising and $\mathrm{R} \& \mathrm{D}$. $\mathrm{R} \& \mathrm{D}$ is more effective than advertising in contributing to brand equity when it comes to 
absolute expenditures. In other words, brand equity was more influenced by total R\&D expenditures than total advertising expenditures. However, advertising is more effective than $\mathrm{R} \& \mathrm{D}$ in contributing to brand equity with respect to changes in expenditures. This could mean that R\&D is more effective than advertising in contributing the total value of brand equity, whereas advertising is more effective than $R \& D$ in contributing to the marginal value of brand equity.

These findings have theoretical and managerial implications. First, from a theoretical point of view, the findings show that advertisings do affect brand equity. Thus, it can be a primary source of developing and maintaining relationships with a firm's stakeholders including consumers and channel members. These relationships become relational marketbased assets, which have been suggested to enhance shareholder values. As a traditional approach of advertising effectiveness research, the market response analysis usually measures the effectiveness of advertising in relation to market performance measures like sales volume and market share. In comparison, however, the present research suggests another approach to evaluate advertising effectiveness by employing the concept of brand equity. This is because advertising cannot only work to improve market performance measures, but also can contribute to brand equity.

Second, in terms of the managerial implications, the potential of R\&D to enhance brand equity can be realized by improving intellectual market-based assets. Since the present research shows that R\&D can contribute to brand equity, managers can take advantage of these findings and consider $R \& D$ as a legitimate option to generate value for brands and firms in the future. In addition, advertising can also be perceived and utilized to generate value for brands and firms. Advertising is a favourite discretionary expenditure for managers to reduce, especially when they are under severe pressure to improve profits. However, given the present findings, managers can argue that advertising not only influences sales and market share but also brand equity. Considering an argument that brand equity will be the most important value generator for brands and firms in the future (Aaker, 1991, 1996; Keller, 1993; Srinivasan, et al., 2005), it is reasonable to consider advertising as an investment rather than an expense.

This result holds high potential to alter marketers' traditional views on ways to allocate budgets on advertising and R\&D expenditures. As Mizik and Jacobson (2003) argued, advertising and R\&D are the two major expenditures, but, at the same time, compete for funds available in business organizations. Here, in trying to allocate limited resources between value generation and value appropriation, trade-offs between the two often occurs. However, this study shows that the firms can have more effective results when marketers invest on advertising and $R \& D$ together. In fact, advertising and R\&D expenditures could affect brand equity by improving relational market-based assets and intellectual market-based assets respectively.

\section{Limitations}

The first limitation of the present research results from the data sets. The methodology for brand value estimates by Financial World and Interbrand Group was not a perfect tool to measure brand equity. In fact, their methodology was something that could be easily replaced by many other methodologies for fulfilling the same purpose.

Further limitations regarding the data sets used in the present research relate to data obtained from the Compustat PC-Plus database. This data source is dependable and reliable for empirical analyses (Mizik \& Jacobson, 2003; Kerin \& Sethuraman, 1998), however, its accuracy cannot be fully warranted. This concerns especially with advertising because data on advertising expenditures from the Compustat PC-Plus database usually include expenditures on other marketing communications like consumer promotions. Thus, it is not the most precise advertising data if the exact data on advertising expenditures were required (Graham \& Frankenberger, 2000; Mizik \& Jacobson, 2003).

Besides the quantity aspect of advertising like the level and duration of advertising expenditures, the quality aspect of advertising (conventionally called "advertising creative") may affect the effectiveness of advertising in enhancing the value of brand equity. The exact same media plan with different creative (e.g., TV commercials in the same spot in the same broadcasting companies) may produce different results in terms of advertising effectiveness. Both the current and potential customers may perceive and evaluate advertising differently depending on how attracted they are to advertising for a certain brand. By the same token, R\&D expenditures may not reflect the qualitative aspect of $R \& D$ efforts because spending money on R\&D does not necessarily lead to superior intellectual market-based assets.

\section{References}

Aaker, D.A. 1991. Managing brand equity: capitalizing on the value of a brand name. New York: The Free Press.

Aaker, D.A. 1996. 'Measuring brand equity across products and markets', California management review, 38(3): 103.

Aaker, D.A. \& Jacobson, R. 1994. 'The financial information content of perceived quality', Journal of Marketing Research: 191201.

Aaker, D.A. \& Jacobson, R. 2001. 'The value relevance of brand attitude in high-technology markets', Journal of marketing research, 38(4): 485-493.

Ailawadi, K.L., Donald, R.L. \& Scott, A.N. 2003. 'Revenue premium as an outcome measure of brand equity', Journal of Marketing, 67(October): 1-17.

Anderson, E.W., Fornell, C. \& Mazvancheryl, S.K. 2004. 'Customer satisfaction and shareholder value', Journal of Marketing, 68(4): 172-185. 
Assmus, G., John U.F. \& Donald, R.L. 1984. 'How advertising affects sales: Meta-analysis of econometric results', Journal of Marketing Research, 21(February): 65-74.

Bass, F.M. 1969. 'A simultaneous equation regression study of advertising and sales of cigarettes', Journal of Marketing Research, 6(August): 291-300.

Bass, F.M. \& Clarke, D.G. 1972. 'Testing distributed lag models of advertising effects', Journal of Marketing Research, 9(August): 298-308.

Bass, F.M., Bruce, N., Majumdar, S. \& Murthi, B. 2007. 'Wear out effects of different advertising themes: A dynamic Bayesian model of the advertising-sales relationship', Marketing Science, 26(2): 179-195.

Blattberg, R.C. \& Abel, P.J. 1981. 'A micro-modelling approach to investigate the advertising-sales relationship', Management Science, 27(September): 988-1005.

Borden, N.H. 1952. Economic effects of advertising. Homewood, IL: Richard D. Irwin.

Bowman, D. \& Gatignon, H. 2010. Market response and marketing mix models: Trends and research opportunities. Now Publishers Inc.

Breuer, R., Brettel, M. \& Engelen, A. 2011. 'Incorporating longterm effects in determining the effectiveness of different types of online advertising', Marketing Letters, 22(4): 327-340.

Bruce, N.I., Peters, K. \& Naik, P.A. 2012. 'Discovering how advertising grows sales and builds brands', Journal of Marketing Research, 49(6): 793-806.

Buil, I., de Chernatony, L. \& Martínez, E. 2013. 'Examining the role of advertising and sales promotions in brand equity creation', Journal of Business Research, 66(1): 115-122.

Burmann, C., Jost-Benz, M. \& Riley, N. 2009. 'Towards an identitybased brand equity model', Journal of Business Research, 62(3): 390-397.

Chu, S. \& Keh, H.T. 2006. 'Brand value creation: Analysis of the interbrand-business week brand value rankings', Marketing Letters, 17(4): 323-331.

Clulow, V., Barry, C. \& Gerstman, J. 2007. 'The resource-based view and value: The customer-based view of the firm', Journal of European Industrial Training, 31(1): 19-35.

Dahlhoff, D. 2002. Marketing-related motives in mergers \& acquisitions. Deutscher Universitätsverlag.

Daidj, N., Epinette, O. \& Vialle, P. 2004. 'Positioning of firms on an e-business value chain: The case of video on demand', Management, 5: 10.

Deighton, J., Henderson, C.M. \& Neslin, S.A. 1994. 'The effects of advertising on brand switching and repeat purchasing', Journal of Marketing Research, 31(February): 28-43.

Dekimpe, M.G. \& Hanssens, D.M. 1995. 'The persistence of marketing effects on sales', Marketing Science, 14(Winter): 1-21.
Denison, E. 1962. The sources of economic growth in the United States. New York: Committee for Economic Development.

Erickson, G. \& Jacobson, R. 1992. 'Gaining comparative advantage through discretionary expenditures: The returns to $R \& D$ and advertising', Management Science, 38(September): 1264-79.

Eng, L.L. \& Keh, H.T. 2007. 'The effects of advertising and brand value on future operating and market performance', Journal of Advertising, 36(4): 91-100.

Frels, J.K., Shervani, T. \& Srivastava, R.K. 2003. 'The integrated networks model: Explaining resource allocations in network markets', Journal of Marketing, 67(1): 29-45.

Glazer, R. 1991. 'Marketing in an information-intensive environment: Strategic implications of knowledge as an asset', Journal of Marketing, 55(October): 1-19.

Graham, R.C. Jr. \& Frankenberger, K.D. 2000. 'The contribution of changes in advertising expenditures to earnings and market values', Journal of Business Research, 50(November): 149-55.

Griliches, Z. 1995. R\&D and productivity. In Stoneman, P. (Ed). Handbook of the economics of innovation and technological change. Oxford, England: Blackwell Publishers.

Guellec, D. \& Van Pottelsberghe de la Potterie, B. 2004. 'From R\&D to productivity growth: Do the institutional settings and the source of funds of R\&D matter?', Oxford Bulletin of Economics and Statistics, 66(3): 353-378.

Hall, R. 1993. 'A framework linking intangible resources and capabilities to sustainable competitive advantages', Strategic Management Journal, 14(November): 607-18.

Hanssens, D.M., Leonard, J.P. \& Randall, L.S. 1990. Market response models: Econometric and time series analysis. Boston, MA: Kluwer Academic Publishers.

Herremans, I.M., Ryans, J.L. \& Aggarwal, R. 2000. 'Linking advertising and brand value', Business Horizons, 43(May-June): 1926.

Ho, Y.K., Keh, H.T. \& Ong, J.M. 2005. 'The effects of R\&D and advertising on firm value: An examination of manufacturing and nonmanufacturing firms', Engineering Management, IEEE Transactions on, 52(1): 3-14.

Hunt, S. \& Morgan, R.M. 1995. 'The comparative advantage theory of competition', Journal of Marketing, 59(April): 1-15.

Joshi, A.M. \& Hanssens, D.M. 2009. 'Movie advertising and the stock market valuation of studios: A case of 'great expectations?', Marketing Science, 28(2): 239-250.

Joshi, A. \& Hanssens, D.M. 2010. 'The direct and indirect effects of advertising spending on firm value', Journal of Marketing, 74(1): 20-33.

Keller, K.L. 1993. 'Conceptualizing, measuring, and managing customer-based brand equity', Journal of Marketing, 57(January): $1-22$.

Keller, K.L. 1998. Strategic brand management: Building, measuring, and managing brand equity. Upper Saddle River, NJ: Prentice Hall. 
Kerin, R.A. \& Sethuraman, R. 1998. 'Exploring the brand valueshareholder value nexus for consumer goods companies', Journal of the Academy of Marketing Science, 26(Fall): 260-73.

Kim, H., Kim, W.G. \& An, J.A. 2003. 'The effect of consumerbased brand equity on firms' financial performance', Journal of consumer marketing, 20(4): 335-351.

Kim, K. 2007. The effects of advertising and publicity on corporate reputation and sales revenue: 1985-2005 ProQuest.

Leone, R.P. 1995. 'Generalizing what is known about temporal aggregation and advertising carryover', Marketing Science, 14(3): 141-50.

Leuthesser, L. 1988. Defining, measuring, and managing brand equity: A conference summary by Marketing Science Institute.

Lin, B., Lee, Y. \& Hung, S. 2006. 'R\&D intensity and commercialization orientation effects on financial performance', Journal of Business Research, 59(6): 679-685.

Lodish, L.M., Abraham, M., Kalmenson, S., Livelsberger, J., Lubekin, B., Richardson, B, \& Stevens, M.E. 1995. 'How TV advertising works: A meta analysis of 389 real world split cable TV advertising experiments', Journal of Marketing Research, 32(May): 125-39.

Mansfield, E, Rapport, J., Romeo, A., Wagner, S. \& Beardsley, G. 1977. 'Social and private rates of return from industrial innovation', Quarterly Journal of Economics, 91(May): 221-40.

Meschi, R.L. 1995. 'Value added: Refinements in our brand valuation methodology', Financial World, 164(August 1): 52.

Mizik, N. \& Jacobson, R. 2003. 'Trading off between value creation and value appropriation: The financial implications of shifts in strategic emphasis', Journal of Marketing, 67(January): 63-76.

Morgan, R.M. \& Hunt, S. 1994. 'The commitment-trust theory of relationship marketing', Journal of Marketing, 58(July): 20-38.

Neslin, S.A. 2002. Sales promotion. Cambridge, MA: Marketing Science Institute.

O'Brien, J.P. 2003. 'The capital structure implications of pursuing a strategy of innovation', Strategic Management Journal, 24(5): 415431.

Park, T., Shenoy, R. \& Salvendy, G. 2008. 'Effective advertising on mobile phones: A literature review and presentation of results from 53 case studies', Behaviour \& Information Technology, 27(5): 355373.

Pahud de Mortanges, C. \& Van Riel, A. 2003. 'Brand equity and shareholder value', European management journal, 21(4): 521-527.

Palda, K.S. 1964. The measurement of cumulative advertising effects. Englewood Cliffs, NJ: Prentice Hall.

Parker, P.M. \& Gatignon, H. 1996. 'Order of entry, trial diffusion, and elasticity dynamics: An empirical case', Marketing Letters, 7(January): 95-109.

Pedrick, J.H. \& Zufryden, F.S. 1991. 'Evaluating the impact of advertising media plans: A model of consumer purchase dynamics using single-source data', Marketing Science, 10(Spring): 111-30.
Quandt, R.E. 1964. 'Estimating the effectiveness of advertising: Some pitfalls in econometric methods', Journal of Marketing Research, 1(May): 51-60.

Ramaswami, S.N., Srivastava, R.K. \& Bhargava, M. 2009. 'Marketbased capabilities and financial performance of firms: Insights into marketing's contribution to firm value', Journal of the Academy of Marketing Science, 37(2): 97-116.

Rao, A.G. \& Miller, P.B. 1975. 'Advertising/sales response functions', Journal of Advertising Research, 15(April): 1-15.

Rust, R.T., Ambler, T., Carpenter, G.S., Kumar, V. \& Srivastava, R. K. 2004a. 'Measuring marketing productivity: Current knowledge and future directions', Journal of Marketing, 68(4): 76-89.

Rust, R.T., Zeithaml, V.A. \& Lemon, K.N. 2004b. 'Customercentered brand management', Harvard business review, 82(9): 110120.

Seggie, S.H., Kim, D. \& Cavusgil, S.T. 2006. 'Do supply chain IT alignment and supply chain interfirm system integration impact upon brand equity and firm performance?', Journal of business research, 59(8): 887-895.

Sethuraman, R. \& Tellis, G.J. 1991. 'An analysis of the trade-off between advertising and price discounting', Journal of Marketing Research, 28(May): 160-74.

Sheth, J.N. \& Parvatiyar, A. 1995. 'Relationship marketing in consumer markets: Antecedents and consequences', Journal of the Academy of Marketing Science, 23(Fall): 255-71.

Shocker, A.D., Rajendra, Strivastava, K. \& Ruekert, R.W. 1994. 'Challenges and opportunities facing brand management: An introduction to the special issue', Journal of Marketing Research, 31(May): 149-58.

Solow, R.M. 1957. 'Technical change and the aggregate production function', Review of Economics and Statistics, 39(August): 312-20.

Sridhar, S., Narayanan, S. \& Srinivasan, R. 2014. 'Dynamic relationships among $\mathrm{R} \& \mathrm{D}$, advertising, inventory and firm performance', Journal of the Academy of Marketing Science, 42(3): 277-290.

Srinivasan, V., Park, C.S. \& Chang, D.R. 2005. 'An approach to the measurement, analysis, and prediction of brand equity and its sources', Management Science, 51(9): 1433-1448.

Srinivasan, R. 2006. 'Dual distribution and intangible firm value: Franchising in restaurant chains', Journal of Marketing, 70(3): 120135.

Srinivasan, S. \& Hanssens, D.M. 2009. 'Marketing and firm value: Metrics, methods, findings, and future directions', Journal of Marketing Research, 46(3): 293-312.

Srinivasan, S., Pauwels, K., Silva-Risso, J. \& Hanssens, D. 2009. 'Product innovations, advertising and stock returns', Journal of Marketing, 73(1): 24-43.

Sriram, S., Balachander, S., \& Kalwani, M.U. 2007. 'Monitoring the dynamics of brand equity using store-level data', Journal of Marketing, 71(2): 61-78. 
Srivastava, R., Tasadduq, A.S. and Fahey, L. 1998. 'Market-based assets and shareholder value: A framework for analysis', Journal of Marketing, 62(January): 2-18.

Srivastava, R., Tasadduq, A.S. and Fahey, L. 1999. 'Marketing, business processes, and shareholder value: An organizationally embedded view of marketing activities and the discipline of marketing', Journal of Marketing, 63(Special Issue): 168-79.

Strong, E.K. Jr. 1925. 'Theories of selling', Journal of Applied Psychology, 9(February): 75-86.

Tellis, G.J. 1988. 'Advertising exposure, loyalty and brand purchase: A two-stage model', Journal of Marketing Research, 25(May): 134-44.

Telser, L.G. 1962. 'Advertising and cigarettes', The Journal of Political Economy, 70(October): 471-99.

Telser, L.G. 1964. 'Advertising and competition', The Journal of Political Economy, 72(December): 537-62.

Terui, N., Ban, M. \& Allenby, G.M. 2011. 'The effect of media advertising on brand consideration and choice', Marketing Science, 30(1): 74-91.

Vakratsas, D. \& Ambler, T. 1999. 'How advertising works: What do we really know?', Journal of Marketing, 63(January): 26-43.

Vinod, H.D. \& Rao, P.M. 2000. 'R\&D and promotion in pharmaceuticals: Conceptual framework and empirical exploration', Journal of Marketing Theory and Practice, 8(Fall): 10-20.

Wang, F., Zhang, X.P.S. \& Ouyang, M. 2009. 'Does advertising create sustained firm value? The capitalization of brand intangible', Journal of the Academy of Marketing Science, 37(2): 130-143.

Wang, H.D. 2010. 'Corporate social performance and financialbased brand equity', Journal of product \& Brand management, 19(5): 335-345.

Winer, R.S. 1979. 'An analysis of the time-varying effects of advertising: The case of Lydia Pinkham', Journal of Business, 52(October): 563-76.

Zhou, N., Zhou, D. \& Ouyang, M. 2003. 'Long-term effects of television advertising on sales of consumer durables and nondurables - the case of China', Journal of Advertising, 32(2): 4554 . 